\title{
Between two Stages: Rita Pavone and i giovani on Studio Uno (1961-
}

\section{6).}

Cecilia Brioni

School of Histories, Languages and Cultures, University of Hull, Hull, United Kingdom

\begin{abstract}
This article analyses how Italian young people were represented in the Saturday night television programme Studio Uno (1961-1966). It defines i giovanias a performative identity: i giovani are not described as a specific age group, but rather as a normative identity constructed in popular media through the reiteration of bodily practices defined in opposition to 'adult' practices. Firstly, the article connects the emergence of discourses around $i$ giovani with the educative function of RAI. Secondly, it outlines to what extent 1965 can be considered a turning point for representations of $i$ giovani in Italian media. Thirdly, it compares the two young Studio Uno 1966 co-hosts Mina and Rita Pavone, to highlight the practices through which the latter was constructed as giovane. Lastly, the article suggests how the giovane identity was presented to an audience of adults and youths respectively through a different spatialisation of giovani performers on the show.
\end{abstract}

Keywords: RAl; Studio Uno; giovani; Rita Pavone; Italian young people; 1960s.

Although the emerging role of young people as social and political agents in Italy during the 1960s has been explored by historians and sociologists, ${ }^{1}$ how the popular media shaped the discourse around young people, and the function of popular culture in constructing ideological representations of this collective identity, have been largely overlooked. The subject of the present analysis is indeed not young people as an age group, but igiovani as a performative

\footnotetext{
${ }^{1}$ Paolo Sorcinelliand Angelo Varni have published a history of youth from the end of the 1800 s to the present day, while Franco Crespi's edited book deals with representations of youth from the 1960s to the present from a sociological point of view. See P. Sorcinelli, and A. Varni, eds, Il secolo dei giovani. Le nuove generazioni e la storia del Novecento (Rome: Donzelli, 2004), and F. Crespi, ed., Le rappresentazioni sociali dei giovani in Italia (Rome: Carocci, 2002). The edited volume Ragazzi senza tempo provides an analysis of Italian youth cultures through a series of case studies from the 1960s to the 1990s. See M. Canevacci, A. Castellani, A. Colombo, M. Grispigni, M. Ilardi, and F. Liperi, Ragazzi senza tempo: immagini, musica, conflitti delle culture giovanili (Genoa: Costa \& Nolan, 1993).
} 
This is an Accepted Ma nuscript of a n article published by Taylor \& Fra ncis in Italian Studies on 5 Sep 2017, a vailable online: http://www.tandfonline.com/10.1080/00751634.2017.1370895.

identity constructed in the Italian popular media, in which age is represented through a set of practices defined in opposition to 'adult' practices. While the few analyses of media representations of young people during the 1960s in Italy have focused on the influence of cultural products such as popular songs and teen magazines, ${ }^{2}$ television has only marginally been taken into consideration, as at the time this medium was mainly intended for an audience of adults and families. ${ }^{3}$ To address this gap in scholarly research, this article utilises the successful Saturday night programme Studio Uno ${ }^{4}$ (1961-1966) as a case study to illustrate the increasing presence of a constitutive and defining media discourse around i giovani in Italian television programmes during the 1960s, and to demonstrate how this discourse fulfilled the general educative function of RAI. ${ }^{5}$ After establishing 1965 as a watershed year in media representations of young people, the article concentrates on the last series of the show, broadcast in 1966, to outline the increasingly recognisable practices with which i giovani were identified. To challenge the idea of il giovane as a merely age-related concept the present study compares the stars Rita Pavone and Mina, and it highlights how their personas were constructed in opposition, respectively as a giovane-antidiva and a donna-diva, despite the fact that they were close to the same age. Lastly, the article deals with the spatial division of performing areas in the show, in order to question to whom different representations of young people were directed. The presence of an audience of young people was not only acknowledged, but also encouraged through the strategy of creating a secondary performing space, the pedane, where giovanibands would perform. The creation of a double performing area was thus aimed at creating different ways to present $i$ giovani to an adult and a young audience.

\section{I giovani in Italian popular media}

According to Massimo Locatelli, the images and narratives broadcast by popular media forms such as television, radio, magazines and cinema played a substantial role in the creation of a unified national identity and in the incorporation of the on-going modernising processes in

\footnotetext{
2 The book Anni sessanta comincia la danza, for example, connects the history of young people in the 1960 s with popular songs of the period. See D. Giachetti, Anni sessanta comincia la danza: giovani, capelloni, studenti ed estremisti negli annidella contestazione (Pisa: BFS Edizioni, 2002).

${ }^{3}$ An exception to this is the edited volume P. Ghione, and M. Grispigni, eds, Giovani prima della rivolta (Rome: Manifestolibri, 1998), which has an entire section devoted to representations of youth in popular media, including tel evision.

4 Studio Uno, RAl, RAl Teche Archives, 1961-1966.

${ }^{5} \mathrm{RAl}$, acronym for Radio Audizioni Italiane, is the Italian public broadcasting company.
} 
This is an Accepted Ma nuscript of a n article published by Taylor \& Fra ncis in Italian Studies on 5 Sep 2017, a vailable online: http://www.tandfonline.com/10.1080/00751634.2017.1370895.

Italian post-war society. ${ }^{6}$ For example, Italian popular media represented the emergence of $i$ giovani as a separate category in Italian society, which was affected by the creation of a commercial youth culture and by the new social and political role of young people in Western societies. ${ }^{7}$ The use of the Italian term 'i giovani' comes from the need to distinguish this category from the merely age-related meaning of the expression 'young people': i giovani refers to a social category who directly 'interpellated' ${ }^{8}$ Italian young people in popular media, to use Louis Althusser's terminology. Althusser introduces the term 'interpellation' to describe the action that ideological state apparatuses, such as the media in this case, ${ }^{9}$ perform in order to create ideological subjects. Through the media, ideology can be represented as 'a lived, material practice - rituals, customs, patterns of behaviour, ways of thinking taking practical form $[. . .]^{\prime},{ }^{10}$ in this way favouring the imitation and naturalisation of identities. Television has a significant impact when broadcasting practices to the audience, because it physically enters the domestic space and its programmes seem more realistic than feature films or theatre mise-en-scènes. ${ }^{11}$ In addition, i giovani of the 1960 s should be regarded as a performatively constructed category: drawing on Judith Butler's analysis of the social construction of gender identities, ${ }^{12}$ this article argues that the giovane identity was represented through the reiteration of specific practices such as 'acts, gestures, enactments' ${ }^{13}$ which were performed in opposition to naturalised 'adult' practices. In other words, my analysis focuses on the ways in which media representations of an age group - young people - were performed and constructed by discourse through practices, in order to create a coherent, ideological identity: igiovani.

\footnotetext{
${ }^{6}$ M. Locatelli, 'Prefazione', in M. Buzzi, La canzone pop e il cinema italiano. Gli anni del boom economico (1958-1963) (Turin: Kaplan, 2013), pp. 9-13 (p. 13).

${ }^{7}$ Although 'youth' as a concept suggesting health and strength existed before the Second World War, it can be argued that the post-war period was fundamental in the creation of 'youth' as a social, commercial, and political collectiveidentity. On the emergence of Western youth in the post-war period, see M. Mitterauer, A History of Youth, trans. by Graeme Durphy (Oxford; Cambridge MA: Blackwell, 1993), pp. 225-238.

${ }^{8}$ Althusser introduces the concept of interpellation in L. Althusser, 'Ideology and Ideological State Apparatuses', in Lenin and Philosophy and Other Essays (New York; London: Monthly Review Press, 1971), pp. 127-86.

${ }^{9}$ Buil ding on Althusser, Stuart Hall identifies the media as ideological state apparatuses. S. Hall, 'Culture, the Media and the Ideological Effect', in Mass Communication and Society, ed. by J. Curran, M. Gurevitch and J. Woollacott (London: Edward Arnold, 1977), pp. 315-348 (p. 346).

10 J. Storey, ed., Cultural Theory and Popular Culture: An Introduction, 5th edn (Harlow; London: Longman, 2009), p. 78.

$11 \mathrm{P}$. Lalli, 'La rappresentazione dei gi ovani in tel evisione', in Le rappresentazioni sociali dei giovani in Italia, pp. 41-76 (p. 45).

12 I refer here to the concept of performativity developed in J. Butler, Gender Trouble: Feminism and the Subversion of Identity, 2nd edn (New York; London: Routledge, 1999), and J. Butler, Bodies that Matter: On the Discursive Limits of Sex, 2nd edn (London; New York: Routledge, 2011).

13 Butler, Bodies that Matter, p. 173.
} 
This is an Accepted Ma nuscript of a n article published by Taylor \& Fra ncis in Italian Studies on 5 Sep 2017, a vailable online: http://www.tandfonline.com/10.1080/00751634.2017.1370895.

The emergence of $i$ giovani as a plural and unitary identity in popular media can be arguably placed at the end of the 1950s, when young people started to stand out as social, political and consumer subjects. Simonetta Piccone Stella claims that the period between 1958 and 1962 was marked by an anxious representation of young people in Italian newspapers, caused by the emergence of teppismo, or minor youth delinquency such as stealing cars, hooliganism, and gang wars. ${ }^{14}$ The social preoccupation towards young people was also increased by the subsequent depiction of il giovane as a politically active subject. This was first noticed by the Italian media during the protest against the announcement of an M.S.I. congress in Genoa in $1960 .{ }^{15}$ The media highlighted the growing presence of young people, who wanted to align themselves with the anti-fascist movement even if they did not experience the Fascist dictatorship directly. Journalists named these young demonstrators ' $\mathrm{i}$ giovani con le magliette a strisce': ${ }^{16}$ interestingly, these politically active giovani started to be characterised by the way they dressed, a visible feature that could immediately differentiate themselves from the 'adults'. From the late 1950s, style became indeed one of the elements through which young people expressed their 'refusal' ${ }^{17}$ to accept the previous generation's social conventions, and one of the aspects that was criticised the most by adults in mainstream media. Young people's fashion and hairstyles, which were subsequently appropriated by the fashion industry, challenged established rules concerning gender, national and class identity. For instance, the miniskirt questioned traditional notions of respectability for young women, and the adoption of long hairstyles for young men and short hairstyles for young women disrupted the conventional boundary between masculine and feminine appearance. The widespread adoption of blue jeans by Italian young people regardless of their class belonging was also problematic, as blue jeans were usually connected to American working-class culture.

Italian television also featured the emergence of $i$ giovani at the beginning of the 1960s. However, as Mauro Morbidelli points out, igiovani were not just categorised as deviant subjects through investigative reports, but a 'strategia aziendale'18 was also adopted in entertainment shows to give a reassuring image of young people, and to spectacularise youth cultures in general:

\footnotetext{
14 S. Piccone Stella, 'Rebels Without a Cause: Male Youth in Italy around 1960', History Workshop, 38 (1994), pp. 157-78.

${ }^{15}$ More on this specific event can be found in P. Ginsborg, A History of Contemporary Italy: Society and Politics, 1943-1988 (Hardsworth: Penguin 1990), pp. 256-57.

${ }^{16}$ G. Crainz, Storia del miracolo italiano (Rome: Donzelli Editore, 1996), p. 173.

17 D. Hebdige, Subculture: The Meaning of Style (London: Routledge 1979), p. 3.

18 M. Morbidelli, “'Posso dire una parola?...”. I giovani dentro e davanti la TV', in Giovani prima della rivolta, pp. 179-186 (p. 182).
} 
This is an Accepted Ma nuscript of a n article published by Taylor \& Fra ncis in Italian Studies on 5 Sep 2017, a vailable online: http://www.tandfonline.com/10.1080/00751634.2017.1370895.

La televisione mostra una gioventù disimpegnata e superficiale, limitandosi ad esaltarne gli aspetti ludici più tipici del giovanilismo che proprio in quegli anni conosceva una grande diffusione: le nuove mode canore, provenienti inizial mente dalla Francia, i balli importati dall'America che ogni anno si rinnovano, il successo degli urlatori e dei primi rockers, diventano così occasione per nuove trasmissioni e per un parziale ricambio di programmi e conduttori. ${ }^{19}$

In other words, the media construction of $i$ giovani might echo that summarised by Dick Hebdige in his study of post-war media representations of British subcultures. According to Hebdige, youth tends to be represented by the media either as 'youth-as-trouble' - criminal, delinquent youth-or as 'youth-as-fun'-commercial, consuming youth. ${ }^{20}$ In the Italian media, the 'giovane-as-fun' image involved a negotiation of meanings: it incorporated the social and political struggle between generations by redirecting it to other fields, in particular those freetime activities that characterised young people's consumption, especially from 1965 onwards. These activities included the making, singing of, and dancing to giovane musicas well as bodily expressions like style and fashion. The media construction of $i$ giovani was beneficial on the one hand to make youth an intelligible category for Italian society at large, including young people themselves, and make them 'harmless' and reassuring for the adult audience. On the other hand, it favoured the creation not only of a homogenised community of subjects with similar interests, but also of a group of consumers with similar tastes: the promotion of goods specifically marketed towards young people enhanced the consumption of an increasingly numerous portion of Italian society.

The 'giovane-as-fun' image started to appear in Italian entertainment television shows during the early 1960s: for example, the programme Alta pressione ${ }^{21}$ was entirely dedicated to i giovani. In the first episode, the host Renata Mauro invited the audience to 'scoprire i giovani d'oggi' $^{22}$ through music performances involving giovani stars. Media representatives of $i$ giovanibecame indeed those singers who, through their star persona, expressed a contrast to the 'adults', such as Adriano Celentano in 1959-60 and, from 1962 onwards, Rita Pavone and Caterina Caselli. These stars' media presence, as hosts, singers, dancers or - as in Pavone's case - all three combined, favoured the identification of or, as Edgar Morin defines it, the

\footnotetext{
19 Ibid., pp. 182-83.

20 D. Hebdige, Hiding in the Light: On Images and Things (London; New York: Routledge, 1988), p. 19.

${ }^{21}$ Alta pressione, RAl, RAl Teche Archives, 1962.

22 'Series 1, Episode 1', Alta pressione, RAI, RAl Teche Archives, 16 September 1962.
} 
This is an Accepted Ma nuscript of a n article published by Taylor \& Fra ncis in Italian Studies on 5 Sep 2017, a vailable online: http://www.tandfonline.com/10.1080/00751634.2017.1370895.

'mimetism' of the young audience: 'the stars guide our manners, gestures, poses, attitudes' 23 and also the way we dress, the music we like, the practices we experience. Moreover, as Simon Frith points out, ${ }^{24}$ a stars' music performance involves not only the actual song, but also the performer's body movements, his/her costumes, and the space in which he/she performs. In a live or recorded performance the body and appearance of the singer is a form of communication through which movements and garments become signs. Stars can thus help in transmitting and reifying those signs, and relating them to specific identities, such as in this case igiovani.

The role of these giovanistars on Italian television can be better understood in light of the political function of RAI during the 1960s. The appointment of Ettore Bernabei, Amintore Fanfani's 'uomo di fiducia', ${ }^{25}$ as RAI general director in 1961 strengthened the political control over national television. During the so-called 'Bernabei era' (1961-1974), RAI was meant to fulfil two main functions: firstly, it was aimed to 'educare cristianamente' ${ }^{26}$ the audience. An emphasis was given to the pedagogical function of the new medium, which was not only supposed to educate the (still in part illiterate) Italian audience, but also to spread Christian values and strongly censor representations of bodies and sexuality. Secondly, RAI programmes were designed to achieve what one hundred years of history had not yet accomplished: that is, to unify Italians. RAI was used by post-war politicians to contribute to the creation of a common national identity: as Giulia Guazzaloca points out, during the 1960s,

la radio e la televisione dovevano diventare i mezzi con cui realizzare quella 'via italiana' alla modernizzazione che coniugasse novità e tradizioni, valori cristiani e consumismo di massa, egualitarismo sociale e anticomunismo. ${ }^{27}$

The presence of giovani stars in entertainment shows of the 1960s, then, can be seen as a device to help the audience understand and characterise a 'modern' subject such as Italian giovani. Just like the striped t-shirts used by the anti-fascists in Genoa in 1960, these giovani started to be identified by the media through their specific styles, dances, songs, clubs and a

\footnotetext{
23 E. Morin, The Stars (London: Evergreen Books, 1961), p. 166.

24 S. Frith, Performing Rites: On the Value of Popular Music (Cambridge, Massachusetts: Harvard University Press, 1996), pp. 203-25.

${ }^{25}$ Amintore Fanfani was a prominent member of the Christian Democratic Party and Italian Prime Minister for several legislatures, including the period from 1960 to 1963 . He was the politician who facilitated Bernabei's appointment as RAl director, in this way securing a political control over national television. See G. Guazzaloca, Una e divisibile: La Rai e i partiti negli annidel monopolio pubblico (Florence: Le Monnier, 2011), p. 125.

26 Ibid.

27 Ibid., p. 141.
} 
This is an Accepted Ma nuscript of a n article published by Taylor \& Fra ncis in Italian Studies on 5 Sep 2017, a vailable online: http://www.tandfonline.com/10.1080/00751634.2017.1370895.

language that mainly referred to free-time activities. These representations suggest that television - and all the political, commercial, and social institutions influencing it - aimed to dispel anxieties towards the increasing politicisation and potential dangerousness of young people. Moreover, the creation of specific giovaniltalian stars had the function of nationalising a subject who was particularly influenced by transnational experiences: Arthur Marwick defines the 'High Sixties' (1964-1969) as the era of the 'British Invasion' for the four countries he analyses (Britain itself, United States, France, and Italy), ${ }^{28}$ a cultural invasion specifically aimed at young people. The media representation of Italian ways of being young through Italian giovanistars was thus beneficial in homogenising and nationalising discourses around youth during the 1960 s.

\section{Evolving giovani in Studio Uno}

Both the educating and the homogenising functions of television are identifiable in the construction of i giovani in Studio Uno. Studio Uno (1961-1966) has been one of the most innovative and successful TV programmes in the history of Italian television. ${ }^{29}$ Broadcast on Saturday nights for four series from 1961 to 1966, it was the first big 'light entertainment' show in Italy, showcasing a series of performances including songs, dance routines and comic sketches. The contents of the programme, the day and time of broadcasting, and the social function of television during the 1960s in Italy suggest that the programme was directed to an audience mainly composed of adults and families. The show was extremely successful: according to its director, Antonello Falqui, up to twenty-two million people used to watch Studio Uno. ${ }^{30}$

Throughout the four series, not only did the structure of the programme change, but the content also testifies to a rising visibility of i giovani and an increased definition of their identity. Representations of igiovani in Studio Uno were not uniform during the whole period in which the programme was broadcast, but they were influenced by the transformations of the attitudes towards young people in Italian society. As Butler explains in her analysis of the construction of gendered subjects:

\footnotetext{
${ }^{28}$ A. Marwick, The Sixties: Cultural Revolution in Britain, France, Italy and the United States, c.1958c.1974 (Oxford: Oxford University Press, 1998).

${ }^{29}$ See A. Grasso, Storia della televisione italiana: nuova edizione aggiornata (Milan: Garzanti, 2004), p. 104, and C. Ferretti, U. Broccoli and B. Scaramucci, Mamma Rai: storia e storie del servizio pubblico radiotelevisivo (Florence: Le Monnier, 1997), pp. 238-39.

30 'Antonello Falqui: Giochiamo al varietà', La storia siamo noi, <http://www.lastoriasiamonoi.rai.it/puntate/antonello-falqui/931/default.aspx>[Accessed: 13 December 2013].
} 
This is an Accepted Ma nuscript of a n article published by Taylor \& Fra ncis in Italian Studies on 5 Sep 2017, a vailable online: http://www.tandfonline.com/10.1080/00751634.2017.1370895.

what the person 'is' [...] is always relative to the constructed relations in which it is determined. As a shifting and contextual phenomenon, gender does not denote a substantive being, but a relative point of convergence among culturally and historically specific set of relations. ${ }^{31}$

Similarly, igiovaniwere differently constructed by the media over time, and representations were influenced by cultural, social, and historical factors. In particular, this section demonstrates that the period around 1965 can be considered a turning point for media representations of young people, as a proliferation of discourses around youth took place in Italian popular media.

Bodily representations of young people in the first series of Studio Uno (1961) expressed the unintelligibility of a social category that was still not clearly defined by the media. For example, in a dance performance ${ }^{32}$ choreographed by Don Lurio where the corps de ballet is named 'le ragazze d'oggi' and 'i ragazzi d'oggi', the lyrics of the song accompanying the choreography emphasise the incommunicability between i giovani and the 'adults' by insisting on the fact that i giovani don't say 'I love you' anymore, but obscure words (that in the song are actually just meaningless sounds). Moreover, at the beginning of the performance, the choreographer explains that 'il mondo è impazzito, la vita è come un quadro di Picasso': the connection between i giovani and concepts like madness and abstract art underlines the difficulties in understanding igiovani's culture. The difference of igiovani is also emphasised by the futuristic and artificial shape and pattern of the dancers' costumes. This representation, then, insists on i giovani's modernity, but also underlines that they possess traits which are indefinable for adults.

During the second series (1962-63), singer and television personality Rita Pavone ${ }^{33}$ was a regular host of the show, performing a song in every episode of the entire series: the singer never spoke to the audience, but still through her performances she embodied il giovane. According to Deborah Toschi, 'fin dalle prime note, il personaggio della Pavone articola la propria visibilità e il proprio successo intorno al tema dell'età, che risulta fondamentale nella creazione della sua immagine': ${ }^{34}$ Pavone's career has thus been based on her performance of

\footnotetext{
31 Butler, Gender Trouble, p. 15.

32 'Series 1, Episode 3', Studio Uno, RAI, RAI Teche Archives, 04 November 1961.

33 Rita Pavone's career had just started. In 1962, Pavone won the Festival degli sconosciuti in Ariccia after which she started her recording career.

34 D. Toschi, 'Maschere e vocalità di una ragazza yé-yé: il caso Rita Pavone', Comunicazione sociale 1 (2011), pp. 74-83 (p. 75).
} 
This is an Accepted Ma nuscript of a n article published by Taylor \& Fra ncis in Italian Studies on 5 Sep 2017, a vailable online: http://www.tandfonline.com/10.1080/00751634.2017.1370895.

the giovane identity, which constitutes a fundamental reference point in the construction of $i$ giovani in Studio Uno. Pavone's 1962-63 performances depict i giovani while doing specific free-time activities, such as attending a football match, ${ }^{35}$ dancing with friends at a house party, ${ }^{36}$ going on a winter holiday, ${ }^{37}$ and everyday activities such as going to school ${ }^{38}$ and working as shop assistants. ${ }^{39}$ However, most of Pavone's performances in this series clearly recall childhood practices: the singer always wears circle skirts and ballet pumps, and the setting sometimes includes toys and children's games, such as a giant doll, ${ }^{40}$ or a giant miniature train and a choreography involving a Ring a Ring-o' Roses. ${ }^{41}$ The connection between i giovani and childhood in Studio Uno 1962-63 shows a lack of definition in the giovane identity, that still needed to refer to other age groups' practices in order to be distinguished from the 'adults'.

In Studio Uno's third series, broadcast in 1965, the association between igiovani and childhood disappeared. Not only did igiovani start to be represented as a separate category, but, unlike the previous series, they were also constructed in direct opposition with the 'adults'. The series introduced a domestication of discourses around the generational struggles of Italian society at the time ${ }^{42}$ in the form of a musical challenge between igiovani and the 'adults': the first and second episode of the series opened with a singing battle between 'maggiorenni' and 'minorenni', in which an 'adult' and a giovane singer were judged by the studio audience. However, the choice of the terminology still suggests the definition of $i$ giovanithrough age; moreover, from the third episode, this slot was no longer present in the show. The host Lelio Luttazzi explains to the audience that the slot was cancelled because the programme was too long if it was included. ${ }^{43}$ The choice of cancelling this specific part of the

\footnotetext{
35 'Series 2, Episode 3', Studio Uno, RAI, RAI Teche Archives, 05January 1963.

36 'Series 2, Episode 6', Studio Uno, RAI, RAl Teche Archives, 26 January 1963, and 'Series 2, Episode 8', Studio Uno, RAl, RAl Teche Archives, 16 February 1963.

37 'Series 2, Episode 7', Studio Uno, RAI, RAl Teche Archives, 02 February 1963.

38 'Series 2, Episode 4', Studio Uno, RAI, RAl Teche Archives, 12 January 1963.

39 'Series 2, Episode 9', Studio Uno, RAl, RAl Teche Archives, 23 February 1963.

40 'Series 2, Episode 5', Studio Uno, RAl, RAl Teche Archives, 19 January 1963.

41 The episode has not been identified but it is part of the second series of Studio Uno, RAI, RAl Teche Archives.

42 Even if much more attention has been given by Italian historiography to il sessantotto, social and political protests carried out mainly by young students were already taking place in Italy during the period 1965-67. In particular, these protests concentrated on school reforms (for example, the 'battle' for the settimana corta at school in 1965), and sexual education in schools (for instance, in the aftermath of La Zanzara affair, in 1966). More on this can be found in Ghione and Grispigni, eds, Giovani prima della rivolta, and Giachetti, Anni sessanta comincia la danza.

43 'Series 3, Episode 3', Studio Uno, RAI, RAl Teche Archives, 27 February 1965.
} 
This is an Accepted Ma nuscript of a n article published by Taylor \& Fra ncis in Italian Studies on 5 Sep 2017, a vailable online: http://www.tandfonline.com/10.1080/00751634.2017.1370895.

programme as a consequence of the lack of time also arguably shows how the opposition giovane/'adult' was not yet extensively used in Italian popular culture.

The fourth series (1966), instead, directly interpellated young people for the first time, reflecting the broader interest of Italian popular media in the young audience. From 1965, a proliferation of media forms specifically directed at young people as an audience took place. BIG: il settimanale giovane was first published in June 1965 after the success of the magazine Ciao amici, first published in 1963. The magazine Marie Claire changed its name to Giovani, officially becoming a giovane magazine in 1966. These giovani magazines mainly featured music and gossip on music stars; however, they also included reports on fashion trends, society and news from foreign countries, especially the United Kingdom. Moreover, as Daniele Magni points out, ${ }^{44}$ the period between 1965 and 1967 was the most productive of the Musicarello film genre: in these films, not only did the giovani stars actively promote their records, but they also presented a specifically giovane language and style to their fans. Television started to consider young people as a target audience through programmes such as Stasera Rita,${ }^{45}$ hosted by Pavone, and Diamoci del tu,${ }^{46}$ hosted by Caterina Caselli and Giorgio Gaber. In these entertainment programmes, the hosts exclusively addressed young people watching the show from home, by using terms like 'ragazzi' or 'giovani'. Radio programmes, and most notably Bandiera gialla, hosted by Renzo Arbore and Gianni Boncompagni and broadcast from 1965 to 1970, were also media forms specifically directed at Italian youths. These television and radio shows mainly had a musical theme, but they also discussed the problematic relationships between $i$ giovani and 'adults'. For instance, the television programme Diamoci del tu featured a weekly comic sketch called 'tribuna beat', in which an 'adult' person, usually a role performed by a comedian, was put on mock trial in front of a court of giovani. Not only did these sketches magnify the incommunicability between igiovani and the 'adults' by insisting on differences between the two groups' language, music and style, but by using comedy they also trivialised some common themes of inter-generational struggles, such as the alleged lack of respect of $i$ giovani for their parents and the habit of young people running away from home - a practice that, according to giovani magazines, was particularly common amongst Italian youth. These media forms, then, started to directly interpellate young people while at the same time contributing to the construction of the category itself, by defining those traits, appearances and behaviours which were considered as

\footnotetext{
44 D. Magni, Cuori matti: dizionario dei musicarelli italiani anni '60 (Milan: Bloodbuster, 2012), pp. 38-39.

45 Stasera Rita, RAl, RAl Teche Archives, 1965.

46 Diamoci del tu, RAI, RAl Teche Archives, 1967.
} 
This is an Accepted Ma nuscript of a n article published by Taylor \& Fra ncis in Italian Studies on 5 Sep 2017, a vailable online: http://www.tandfonline.com/10.1080/00751634.2017.1370895.

belonging to i giovani and those which were not. This process gave igiovania status of their own, which did not need to refer to childhood in order to be distinguished from the 'adults'.

This proliferation of popular media products aimed at young people influenced the presence of i giovanion Studio Uno 1966. The 1966 series was divided into four cycles made of five episodes each, and while musician and presenter Lelio Luttazzi was the main host of the whole series, he wasjoined by four different female co-hosts, who led one cycle each: actress Sandra Milo, and singers Ornella Vanoni, Rita Pavone and Mina. The role of the co-hosts was to lead the last slot of the show, performing and introducing guests. In this series, i giovani started to be a substantial part of the cast of the show: throughout the season the set featured one or two pedane within the audience area, which were exclusively used for the performances of giovani singers and bands. In particular, the cycle co-hosted by Pavone featured igiovani's difference with the 'adults' as a main topic in the show, not only through the presence of Pavone herself, but also through the performances of giovani guest stars, comic sketches on the incommunicability between i giovani and 'adults' performed by Bice Valori and Walter Chiari, and a memorable opening theme - 'Il Geghegè', by Bruno Canfora that further highlighted the different language used by i giovani to communicate. ${ }^{47}$

Articles in Italian teen magazines such as Big welcomed the choice of introducing $i$ giovani on Studio Uno 1966:

La cintura di salvataggio [per Studio Uno] è dunque proprio questa ragazzina antidiva [...]. Una ragazzina che vi salva uno spettacolo nel momento giusto [...], che dice nell'orecchio di Falqui e Sacerdote: 'Volete salvare tutto? Allora fate così. Anche quando non sarò in scena con i collettoni e le collettine, non vi dimenticate che avete deciso di piacere ai giovani. Quindi niente vecchi tromboni e battute cretine'. ${ }^{48}$

The arrival of Pavone and i giovani on Studio Uno is emphasized in the article, and it is presented as the recognition of young people's social influence. The quotation also shows how Italian teen magazines identify Pavone as a spokesperson for igiovani, as she seems successful enough to influence the director's and the screenwriter's decisions and to appeal to the young

\footnotetext{
47 The lyrics of the song 'Il Geghegè' (Canfora, 1965) invite i giovani to use the expression 'geghegeghegeghegè' in order to 'dire quello che vuoi, ma che dire non sai'. A meaningless phrase, then, becomes part of the language through which the giovane community can express itself. 48 S. Modugno, 'Stasera Rito: Rita Pavone lancia il fratello in “Studio Uno”', Big, 18.2 (6 May 1966), pp. 10-12 (p. 11).
} 
This is an Accepted Ma nuscript of a n article published by Taylor \& Fra ncis in Italian Studies on 5 Sep 2017, a vailable online: http://www.tandfonline.com/10.1080/00751634.2017.1370895.

audience at home.

\section{Young versus Giovane: Mina versus Rita}

In order to explore the practices through which the giovane identity was constructed in Studio Uno 1966, an analysis of Pavone's star persona and a comparison between Pavone and Mina is beneficial in the light of the former's media role as a representative for $i$ giovani. The quotation above defines the 1966 Studio Uno co-host Rita Pavone as an 'antidiva': the choice of this term to describe the giovane star proves how the giovane identity was often presented in opposition to 'adult' roles such as, for women in the media, the diva. A comparison between Pavone and Mina, Studio Uno's ultimate diva, ${ }^{49}$ is hel pful not only because the two singers had the same co-hosting role in the show, but also because they were a similar age. Mina was only five years older than Pavone, and as she was under 30 at the time of the show, she could still be considered 'young' in age. However, her star persona was constructed as a donna, while Pavone embodied the giovane identity. The difference between the two singers was rendered in the show through several strategies that connected their star persona with those practices constructing the donna and the giovane as ideological identities.

The contrast between Pavone and Mina is firstly delineated by the way in which the two singers are named in the show: the choice of terms signals an ideological definition of social categories. In Studio Uno 1966, Mina is always referred to as a 'donna', while Pavone is named a 'ragazzina'. ${ }^{50}$ Moreover, when introducing a performance in which Mina sings several Beatles' songs, she refers to i giovani with a 'voi': ${ }^{51}$ by using the second person plural pronoun, Mina distances herself from the category she is interpellating. Pavone instead always talks about i giovani using the pronoun 'noi': in this way, she declares her belonging to the community of igiovani.

The use of the plural pronouns 'noi' and 'voi' in referring to i giovani also suggests the plural, communitarian construction of i giovani in popular media. Jacopo Tomatis claims that during the 1960s young people started to 'perceive themselves as a social group, a national community with shared values and tastes'. ${ }^{52}$ The idea of youth as a community was often

\footnotetext{
49 R. Haworth, 'Making a Star on the Small Screen: The case of Mina and RAl', Journal of Italian Cinema \& Media Studies, 3.1-2 (2015), pp. 27-41 (p. 32).

50 Walter Chiari refers to Pavone as a 'ragazzina' in 'Series 4, Episode 11', Studio Uno, RAI, RAl Teche Archives, 23 April 1966.

51 'Series 3, Episode 3', Studio Uno, RAl, RAl Teche Archives, 27 February 1965.

52 J. Tomatis, "This is Our Music': Italian Teen Pop Press and Genres in the 1960s', IASPM@journal 4. 2 (2014), pp. 24-42 (p. 30).
} 
This is an Accepted Ma nuscript of a n article published by Taylor \& Fra ncis in Italian Studies on 5 Sep 2017, a vailable online: http://www.tandfonline.com/10.1080/00751634.2017.1370895.

conveyed in media representations by portraying young people in a group: in Studio Uno this effect was given by the presence of Pavone's corps de ballet, the Collettoni and (starting some episodes later) the Collettine. The Collettoni and the Collettine were a constant presence during Pavone's television appearances throughout the singer's 1960s and, in part, 1970s career. ${ }^{53}$ They introduced Pavone's performances, usually with a song, symbolising the authority given by young people to Pavone as their representative. Moreover, with the first appearance of these dancers in Studio Uno 1966 Pavone tells the audience that she needs their support in order to get overher stage fright. The usefulness of the community of igiovani is underlined, as if being in a group would make young people stronger. Also, the fact that Pavone expresses a fear of being on stage underlines her anti-diva construction: Pavone's claim of feeling uncomfortable on stage makes her an ordinary person, far from those aspects of divinisation that are considered to be part of the construction of a star. ${ }^{54}$

On the contrary, Lelio Luttazzi alone introduces Mina solemnly: 'Signore e signori... Mina!'. Unlike Pavone, Mina rarely performs with someone else on stage. Mina's solitude on a stage that is frequently empty and the stillness of her performances can be interpreted as a strategy for emphasising her extraordinary vocal and bodily features. Mina is constructed as a diva: when she sings the camera lingers on her face and gestures, through which she expresses and transmits emotions to the audience. ${ }^{55}$ Moreover, in the 1966 series, Mina's heavy makeup and bleached hair offer a sexualised image of the singer, which was absent from her previous appearances in the show. Costumes also accentuate Mina's trademarks: in her history of fashion and RAI, Fabiana Giacomotti points out that Mina's costumes in Studio Uno were designed to highlight hands and shoulders. ${ }^{56}$ The stress on hands accentuated the singer's gestures and thus emotions, while the focus on shoulders can be seen as a strategy to emphasise the upper part of the body without concentrating on the breasts, therefore showing a respectable sexiness. Additionally, in the 1966 series Mina wears long and fitted evening dresses. Although these outfits add drama to the singers' performances, they do not let her move, so that even if she tries to dance, she can only outline movements.

In Pavone's case, the audience's attention is focused instead on her entire body. Movement defines Pavone's performances, as she always dances with her corps de ballet, thus

\footnotetext{
53 First appearing in Pavone's performances in Studio Uno, 1962-63, the Collettoni and the Collettine kept on introducing Pavone's performances in the programmes Stasera Rita, Studio Uno 1966, and in Ciao Rita, RAl, RAl Teche Archives, 1971.

54 Morin, The Stars, pp. 37-68.

55 Haworth, 'Making a Star on the Small Screen', p.32.

${ }^{56}$ F. Giacomotti, La TV alla moda: stile e star nella storia della RAI (Rome: Silvana Editoriale, 2015), p. 21.
} 
This is an Accepted Ma nuscript of a n article published by Taylor \& Fra ncis in Italian Studies on 5 Sep 2017, a vailable online: http://www.tandfonline.com/10.1080/00751634.2017.1370895.

affirming the importance of music and dance as part of the giovane identity. The entire body in motion becomes Pavone's trademark, as a description of the singer in the magazine Big shows: 'Si muove sempre. Oltre che con la bocca, parla con le mani, con i piedi, con la testa, con le braccia. Fa venire il mal di mare'. ${ }^{57}$ Movement is also recalled when Pavone does not dance: for example, when she speaks after a performance, she does so with shortness of breath thus underlining the physical exertion of being giovane.$^{58}$ Style also accentuates the importance of motion: Giacomotti notices that Pavone's costumes in the show were designed to

enfatizza[re] il carattere volitivo e la giovane età puntando sul binomio bianconero per [Pavone] e per tutto il suo corpo di ballo, i 'collettoni' e le 'collettine': abito optical, calze nere, stivaletti a tacco basso, ideali anche pervalorizzare le complesse coreografie di Hermes Pan. ${ }^{59}$

Pavone's style was not only determined by the singer's need to dance during her performances, but also by the trends promoted by the newly-formed youth fashion industry. ${ }^{60}$ The most noticeable change in Pavone's persona from her appearances in the 1962-63 series of Studio Uno to Studio Uno 1966 is indeed her style. Even if the singer does not change her musical repertoire, her style is radically different: it does not recall children's fashion as in 1963 , but it is characterised by low-heeled boots and optical miniskirts. In other words, Pavone's style in the show not only contributes to construct her as a giovane but also defines what style i giovani needed to conform to: the giovane fashion that, according to an article appeared in Big, started to be commercially produced in $1965 .{ }^{61}$

Low heels, short dresses, and the absence of low necklines in costumes emphasised Pavone's bodily difference from Mina and the maggiorate, ${ }^{62}$ busty Italian actresses and television stars of the post-war era. Pavone's costumes tended to stress the absence of curves and the singer's thin physique. Moreover, her androgynous appearance was accentuated by a short haircut and the apparent absence of make up. As Toschi points out, the way in which Pavone's body was presented suggests an ambivalence of sexual roles and an emphasis on

\footnotetext{
57 Modugno, 'Stasera Rito', p. 10.

58 'Series 4, Episode 15', Studio Uno, RAl, RAl Teche Archives, 21 May 1966.

59 Giacomotti, La TV alla moda, p. 91.

60 On the creation of 'youth' fashion, see E. Ewing, History of Twentieth Century Fashion (London: B.T. Batsford LTD, 1974), p. 177.

${ }^{61}$ Anon, 'Chi è senza miti scagli la prima pietra', Big, 1.1 (7 January 1966), pp. 8-13 (p. 10).

62 The term maggiorate has been introduced in the 1950s to define Italian curvy actresses such as Gina Lollobrigida and Sophia Loren. On the origin of this term, see S. Gundle, Bellissima: Feminine Beauty and the Idea of Italy (New Haven; London: Yale University Press, 2007), pp. 149-150.
} 
This is an Accepted Ma nuscript of a n article published by Taylor \& Fra ncis in Italian Studies on 5 Sep 2017, a vailable online: http://www.tandfonline.com/10.1080/00751634.2017.1370895.

adolescence that cancels the singer's sexuality. ${ }^{63}$ This absence of sexuality is evident if we compare Mina's and Pavone's relationships with men on the show: men as potentially sexual or romantic partners are only acknowledged in Mina's case, while with Pavone men always show a paternal attitude. Pavone's first guest on the show is comedian Walter Chiari: the physical difference between the two characters is immediately noticeable, as Pavone is much shorter than Chiari. The comedian's behaviour also suggests a father-daughter relationship, as he greets Pavone by kissing her on the forehead and giving her a flick on the cheek. ${ }^{64}$ Before performing a comic sketch on the national elections, Chiari also establishes his paternal role when he takes Pavone by the hand and accompanies her off the stage to sit amongst the audience because, in Chiari's words, 'Rita non ha l'età'. ${ }^{65}$ However, the singer is twenty years old, only three months away from gaining the right to vote: this quip, more than remarking on Pavone's age, highlights another aspect associated with the giovane identity, that is political disengagement. The construction of i giovani through practices linked to free-time activities produces the image of a politically disengaged giovane who is not interested in opposing the 'adults' except in the form of a musical and style challenge. Although not referring to childhood anymore, Pavone's status as giovane is accentuated by the absence of sexual interest towards her, and by her politically neutral representation.

Conversely, Mina is always greeted by her male hosts with a kiss on the hand or on the cheek, and her guests continuously gaze at her body, as demonstrated by the fact that most of them comment that she has lost weight. Mina is a tall woman who is often taller than her guests, and her height puts her body into the foreground, favouring her objectification. Mina's body is frequently touched, gripped, and kissed by her male guests. In one of the most famous performances of the show, comedian Alberto Sordi defines her 'na fagottata de robba', 'a bunch of stuff' in Roman dialect, in this way literally objectifying her. ${ }^{66}$ Sexual puns are also frequent: when Mina says 'dobbiamo fare qualcosa insieme' to her guest, singer Gilbert Bécaud, he replies 'Spegnete le luci!'. ${ }^{67}$ As Rachel Haworth points out, in Studio Uno Mina conforms 'to the determining male societal and behavioural values of the period'. ${ }^{68}$ Male societal values influence not only Mina's but also Pavone's relation to men, as they both do not speak much in the presence of the male guests of the show. In other words, when

\footnotetext{
63 Toschi, 'Maschere e vocalità', p. 80.

64 'Series 4, Episode 11', Studio Uno, RAl, RAl Teche Archives, 23 April 1966.

65 'Series 4, Episode 12', Studio Uno, RAl, RAl Teche Archives, 07 May 1966.

66 'Series 4, Episode 20', Studio Uno, RAl, RAl Teche Archives, 25 June 1966.

67 'Series 4, Episode 17', Studio Uno, RAI, RAl Teche Archives, 04 June 1966.

68 Haworth, 'Making a Star on the Small Screen', p. 34.
} 
This is an Accepted Ma nuscript of a n article published by Taylor \& Fra ncis in Italian Studies on 5 Sep 2017, a vailable online: http://www.tandfonline.com/10.1080/00751634.2017.1370895.

interacting with men, the right to speak is not given to subordinate identities such as women and igiovani. This explains why Mina can be so overtly harassed, while Pavone's presence is only the excuse to make comic sketches about igiovani.

By being co-hosts, both singers share the role of educating the Studio Uno audience. If, according to Haworth, Mina's role is to broadcast the image of a respectable woman, ${ }^{69}$ Pavone's role is to teach the audience what a respectable giovane is, thus linking this identity not only with specific styles, appearances and bodily practices, but also with appropriate behaviours, such as political disengagement and the absence of sexuality. A comparison between Mina and Pavone confirms how the giovane identity is defined by practices rather than age: the way in which the two singers perform, their style, and their attitude towards men, distinguish and define them more than their generational belonging.

\section{Between two stages: i giovani's performing spaces on Studio Uno 1966}

The educative function of igiovanion Studio Uno 1966 is also related to the space they occupy when performing in the show, which might suggest comparisons to the space given to young people in Italian society. Studio Uno 1966 presented two secondary performing spaces, the socalled pedane, which were separate from the main stage. These pedane werelocated amongst the audience and they were reserved for the performances of giovani bands and singers. Moreover, Lelio Luttazzi clearly defined them as a space for i giovani: he directly addressed young people every time he introduced a band playing in the separate space, calling it 'il vostro palco' and asking the audience to pay attention as one of 'their' stars was starting to play. The pedane thus identified i giovani's performances: when the 'adult' actress Monica Vitti is imitating Caterina Caselli, she sings 'Nessuno mi può giudicare' on the secondary stage, in order to make her imitation more effective. ${ }^{70}$ The pedane spatially changed throughout the four cycles of the 1966 series: in the first two cycles, there were two pedane amongst the audience, and consequently there were two performances of giovanisingers or bands in every episode. In the third cycle, when Pavone was co-hosting the show, Pavone's musical guests on the main stage were mostly giovani singers such as Johnny Halliday, Nancy Sinatra and Carlo Pavone, Rita Pavone's brother, and therefore the pedana was reduced to one, as Luttazzi explains at the beginning of the cycle:

\footnotetext{
69 Ibid.

70 'Series 4, Episode 3', Studio Uno, RAI, RAl Teche Archives, 26 February 1966.
} 
This is an Accepted Ma nuscript of a n article published by Taylor \& Fra ncis in Italian Studies on 5 Sep 2017, a vailable online: http://www.tandfonline.com/10.1080/00751634.2017.1370895.

Questa sera lo stato maggiore di Studio Uno ha deciso che al posto di due pedane ce ne sarà una sola. Ma questo anche in virtù del fatto che data la presenza d[i] Rita Pavone, la quantità di musica dedicata a voi ragazzi nell'economia generale dello spettacolo è già sovrabbondante. ${ }^{71}$

In this cycle, then, the presence of igiovani is defined by Luttazzi as 'sovrabbondante', thus signalling that adults and families remained the preferred audience of the show - and underlining the authority of adults in deciding how much space should be given to i giovani on Studio Uno, and their power to take it away. In the fourth cycle of the series, co-hosted by Mina, the pedana was removed from amongst the audience and put on a side of the main stage. During this last cycle, the only giovane guest regularly playing on the pedana was Caterina Caselli, at the time the most influential giovane singer who was still not a television star. ${ }^{72}$

Despite the presence of giovani singers on both stages, the creation of the pedana seems to establish a hierarchy between 'acceptable' and 'less acceptable' giovani: while some of the giovani performers could be included in the traditional space of the show, other performers were relegated to a secondary space. In order to understand this differentiation, it is essential to describe the performers playing on the pedana, who were mainly popular bands like Equipe 84, The Rokes, I Delfini, I New Trolls, and Rocky Roberts and the Airedales. These giovani differed from the star Rita Pavone because they were less well known by an adult audience. However, they were already popular among young people, as their frequent presence in magazines for young readers testifies. The participation of these bands to Studio Uno 1966 came after several complaints appeared in giovani magazines about the lack of giovani band's performances on Italian television. For instance, a 1965 article in Ciao amici argued that RAI did not allow $i$ giovani to perform on television because of their physical appearance:

No amici, levatevelo dalla testa: [...] tutti i complessi vocali famosi, italiani e stranieri, in televisione non li vedremo mai! Sembra infatti che la commissione di vigilanza radio-televisiva abbia scoperto che la visione di capelli lunghi e spettinati (simbolo ed emblema di molti complessi) suscita nei giovani d'oggi chissà quali

\footnotetext{
71 'Series 4, Episode 11', Studio Uno, RAl, RAl Teche Archives, 23 April 1966.

72 Caterina Caselli's first tel evision show as a host, together with Giorgio Gaber, is Diamoci del tu by Romolo Siena.
} 
This is an Accepted Ma nuscript of a n article published by Taylor \& Fra ncis in Italian Studies on 5 Sep 2017, a vailable online: http://www.tandfonline.com/10.1080/00751634.2017.1370895.

istinti e reazioni; detta commissione ha quindi 'suggerito' ai teledirigenti responsabilidi 'evitare' la comparsa sul video di 'complessi con i capelli lunghi'. ${ }^{73}$

This quotation underlines that these bands were characterised by a specific hairstyle, which was not accepted by the adults for it did not conform to traditional standards of masculine appearance. In Studio Uno 1966, Luttazzi still emphasises the difference in style of these giovani bands. For instance, he introduces the band I Delfini by saying: 'ne vedo uno che sta addirittura dando delle impennate con la testa per sistemarsi a posto i capelli, come un puledro'.${ }^{74}$ The animalisation of the young man here might express the discomfort of the host towards the young man's long hairstyle. To refer to Morin's analysis of James Dean's style, the style of the bands playing on the pedana represented the 'panoply of adolescence', or 'a wardrobe in which is expressed a whole attitude towards society: [...] ostensible signs (having the value of political badges) of a resistance against the social conventions of a world of adults'. ${ }^{75}$ The use of style to differentiate between giovaniand 'adults' was accentuated by the fact that, in Studio Uno, the bands never speak with the hosts, nor is any space given to them in the show except for their musical performances. Their role in the show does not involve any contact with the 'adults' nor with the main stage. This distance magnifies their difference not only from the adult audience but also from Pavone, whose role as a host and her interactions with the guests in the programme make her presence more 'acceptable' to the audience. The previous section has demonstrated how Pavone was presented in Studio Uno as apolitical and asexual: although she was different in style from the 'adults', she was endorsing the ideological rules that made her respectable, while at the same inviting young people to imitate these rules. Conversely, long hairstyles were not only an attribute of male attractiveness for $i$ giovani, but also a typical physical feature of the 'beats di strada', ${ }^{76}$ namely those young people who were starting to gather and protest in big Italian cities such as Milan and Rome. Therefore the giovani bands playing on the pedana were not only sexually attractive to their audience, but they also physically recalled the political young people demonstrating in public places throughout Italy. As a consequence, they were considered as 'less acceptable' for the adult audience, and they were relegated to a secondary space.

\footnotetext{
73 R.C., 'No ai capelli lunghi', Ciao amici, 16.2 (13 November 1965), pp. 25-27 (p. 25).

74 'Series 4, Episode 2', Studio Uno, RAI, RAl Teche Archives, 19 February 1966.

75 Morin, The Stars, pp. 124-25.

76 On the 'beat' phenomenon in Italy, and especially in Milan and Rome, see R. De Angelis, 'Il beat italiano' in Giovani prima della rivolta, pp. 73-84.
} 
This is an Accepted Ma nuscript of a n article published by Taylor \& Fra ncis in Italian Studies on 5 Sep 2017, a vailable online: http://www.tandfonline.com/10.1080/00751634.2017.1370895.

The spatialisation of 'less acceptable' giovani bands might echo spatial issues regarding young people's place in Italian society: the pedana in Studio Uno mirrors the presence of spaces specifically dedicated to young people in Italian towns. For instance, Corso Europa in Milan is described as follows in a 1966 article in Marie Claire Giovani:

Quella strada, dove ci riuniamo, si chiama Corso Europa, ma ormai tutti la indicano come la 'via dei giovani' perché è il luogo fisso dei nostri quotidiani appuntamenti [...]. Qui in Corso Europa ci sono i 'nostri locali': il Copacabana, che funziona tutto il giorno [...]; il Paip's dove andiamo di solito alla sera a ballare [...]. Nella nostra via di giovani ce ne sono sempre. A qualsiasi ora andiamo troviamo sempre qualcuno con cui fare quattro chiacchiere e uno shake. ${ }^{77}$

The quotation shows the strong connection between the giovane identity and spaces specifically designed for young people: Corso Europa here functions as a meeting point for Milanese youth. However, the creation of giovani spaces is ultimately controlled by adults, such as in this case the owners of music clubs. Furthermore, the spaces reserved for igiovani in this street are spaces of disengagement: in these areas, i giovani are only allowed to perform free-time activities connected to the consumption of goods such as music. When young people occupy public spaces, instead, and they express social and political stances, they are seen as out of place. For example, when a community of beatniks from all over Europe held a sit-in at Piazza di Spagna in $1965^{78}$ - thus occupying a public space in order to carry out a peaceful demonstration -they were accused by giovanimagazines of occupying a space that was not 'their own'. ${ }^{79}$

This exclusion might be viewed in relation to Nirmal Puwar's definition of 'space invaders', a term which she uses to identify women and racialized minorities entering political and social spaces from which they have been historically or conceptually excluded. As Puwar puts it,

social spaces are not blank and open for anybody to occupy. There is a connection between bodies and spaces which is built, repeated and contested over time.

\footnotetext{
77 B. Bonazzoli, 'La via dei giovani', Marie-Claire Giovani, 14 (2 April 1966), pp. 6-10 (pp. 9-10).

78 On the capelloni of Piazza di Spagna, see also D. Giachetti, Caterina Caselli: una protagonista del beat italiano (Rome: Alegre, 2006), p. 70.

79 For example in G. Steni, 'Capelloni a congresso. Abbasso il D.D.T.!', Big, 18.1 (7 October 1965), pp. 52 53.
} 
This is an Accepted Ma nuscript of a n article published by Taylor \& Fra ncis in Italian Studies on 5 Sep 2017, a vailable online: http://www.tandfonline.com/10.1080/00751634.2017.1370895.

While all can, in theory, enter, it is certain types of bodies that are tacitly designated as being the 'natural' occupants of specific positions. ${ }^{80}$

Similarly, the relegation of 'less acceptable' giovani to the pedana can be interpreted as a strategy to diminish the anxiety caused by i giovani's invasion of an 'adult' space such as television. Giovanibands are allowed to enter Studio Uno as far as their participation is limited to musicmaking, therefore to an activity considered acceptable and hence naturalised on the television screen. As Doreen Massey has also noted, a limitation and separation of spatiality can be linked to social control, as the 'private' space has traditionally been reserved for women while the 'public' space has been occupied by men. ${ }^{81}$ In Studio Uno the creation of a specific area for 'less acceptable' giovanican symbolise social control over a subordinated and possibly dangerous group.

However, excluding giovani bands from the main stage, and thus highlighting their difference, can also be seen as a strategy to attract an audience of young people. By directly addressing young people, Luttazzi delineates a favourable audience for these performances. A mini-audience of young people dancing and (young women) screaming gathers under the pedane, and the camera takes shots of the bands from a low angle looking up at the stage, in order to make the viewerfeel as if he/she is physically participating in a live concert. As Karen Lury has noticed in her book on 1990s British youth television, recreating a 'live' music performance can be considered a strategy to allow young people to have their own, separate space, and to virtually escape from the family environment in which they are watching television. ${ }^{82}$ As a consequence, young people watching Studio Uno at home would feel simultaneously excluded from the main stage but included in the community of igiovani represented around the pedane. Comedian Bice Valori clearly emphasises this separation by saying that young people only follow the programme because of the artists performing on the pedana. ${ }^{83}$

If the pedana is designed as a space created to relegate 'less acceptable' giovani and to appeal to an audience of young people, the function of the giovani stars occasionally appearing on the main stage is more complex. It can be argued that, as Studio Uno was a programme traditionally aimed at an audience of adults and families, the function of $i$ giovani

\footnotetext{
${ }^{80}$ N. Puwar, Space Invaders: Race, Gender and Bodies out of Place (Oxford; New York: Berg, 2004), p. 8.

81 D. Massey, Space, Place and Gender (Minneapolis: University of Minnesota Press, 1994), p. 179.

82 K. Lury, British Youth Television: Cynicism and Enchantment (Oxford: Clarendon Press, 2001), pp. 4486.

83 'Series 4, Episode 11', Studio Uno, RAI, RAl Teche Archives, 23 April 1966.
} 
This is an Accepted Ma nuscript of a n article published by Taylor \& Fra ncis in Italian Studies on 5 Sep 2017, a vailable online: http://www.tandfonline.com/10.1080/00751634.2017.1370895.

on the main stage was to communicate with this specific section of the audience. Therefore, the familiarity with the giovani stars playing on the main stage was guaranteed by their connection to adult institutions such as the family or the recording industry. For example, giovane singer and actress Romina Power is accepted on the main stage because she performs her role as the daughter of actors Tyrone Power and Linda Christie.$^{84}$ Her status, then, is given by the popularity of herfamily: the questions put to Power after her performance all refer to her father. Similarly, the giovane singer Carlo Pavone is allowed to perform on the main stage because he is Rita Pavone's brother, and the two sing a song together recalling Rita's career. ${ }^{85}$ Other giovani, such as Nancy Sinatra or Johnny Halliday, can access the main stage because they are successful international artists. Their authority is then bestowed for economic reasons by an 'adult' institution, namely the recording industry, which accords them the power to become spokespersons for an entire community via the main stage.

Pavone and Caterina Caselli seem to have a liminal role in the show, which is aimed to please both the adult and the young audience. Pavone is allowed on the main stage because she is a television personality and a successful singer, but she is also a giovane star expressing her difference from the 'adults'. When introducing her, Lelio Luttazzi calls her '[la] vostra, e anche [la] nostra, Rita Pavone', signalling that she is both 'yours' (the young people's audience) and 'ours' (the adults' audience) star. ${ }^{86}$ Similarly, the displacement of the pedana from amongst the audience to next to the main stage when Caselli becomes the regular guest in the last season of the show can be seen as the recognition of Caselli's commercial importance. ${ }^{87}$ This spatial change demonstrates how Caselli can perform next to the main stage because of her commercial power as a singer, but the strategy of leaving her on a separate space is useful to please the young audience.

An analysis of the Studio Uno performing spaces shows how the presence of $i$ giovani both on the main stage and on the pedane had an educative function. On the main stage, Pavone explained what it meant to be giovane by performing specific practices and behaviours, thus educating both the young and the adult audience on the ideologically respectable giovane. The pedana effectively showed adults a spatial control of 'less

\footnotetext{
84 'Series 4, Episode 10', Studio Uno, RAl, RAl Teche Archives, 16 April 1966.

85 'Series 4, Episode 14', Studio Uno, RAl, RAl Teche Archives, 14 May 1966.

86 'Series 4, Episode 11', Studio Uno, RAl, RAl Teche Archives, 23 April 1966.

87 In February 1966, just a few months before the broadcasting of these episodes, Caselli participated to the Sanremo Festival with the song 'Nessuno mi può giudicare'. She did not win the festival; however, the song was an enormous success in terms of record sales. The single sold 500,000 copies, over the 300,000 copies sold by 'Dio come ti amo', the Sanremo festival winner. See Giachetti, Caterina Caselli: una protagonista del beat italiano, p. 49.
} 
This is an Accepted Ma nuscript of a n article published by Taylor \& Fra ncis in Italian Studies on 5 Sep 2017, a vailable online: http://www.tandfonline.com/10.1080/00751634.2017.1370895.

acceptable' giovani and simultaneously pleased the young audience, as it played with the sense of belonging to the community of $i$ giovani by creating a connection between identity and giovani spaces.

\section{Conclusion: The Construction of the Giovane Identity on Studio Uno}

This article has demonstrated how television, and entertainment programmes, can be used as historical sources to problematise the increasing social, political and economic role of young people in 1960s Italy. The presence of i giovani on Studio Uno testifies to the growing recognition of young people as a separate category in Italian society and to a general desire to understand and characterise this emerging generational identity. Images of i giovani, embodied by stars such as Rita Pavone, influenced the social perception of young people, and the overall expectations about this new social agent. The bodily movements, style, and spatialisation of i giovani on Studio Uno 1966 suggested how young people should look, how they should behave and the space they should occupy in Italian society. The construction of il giovane in Studio Uno had the double function of reassuring the adult audience and favouring young people's sense of belonging to a community of peers and their consumption of musical and fashion products. However, the connection between free-time activities and igiovani as broadcast by entertainment shows contributed to the construction of the respectable giovane as a politically and socially disengaged subject.

The definition of $i$ giovani as a performative identity that is constructed through practices rather than expressed by age is a useful tool to analyse how popular media addressed issues of power between generations in the Italian society of the 1960s. Yet, Michel Foucault underlines that 'where there is power, there is resistance'. ${ }^{88}$ Despite outlining the subversive potential ${ }^{89}$ of these representations, this article has not considered the role of young people in resisting the homogenising media construction of i giovani during the 1960s. This aspect is equally overlooked and would thus benefit from further research.

\footnotetext{
88 M. Foucault, The History of Sexuality: An Introduction, trans. by Robert Hurley (New York: Pantheon Books, 1978), p. 95.

${ }^{89}$ On the subversive potential of performative identities, see Butler, Gender Trouble, pp. 163-80.
} 